\title{
Çevrimiçi Seyahat Rehberlerinde Destinasyon Çekicilik Unsurlarının Analizi: "Turkey Home” Örneği
}

Fatih $\operatorname{Ercan}^{1}$

Çevrimiçi Seyahat Rehberlerinde Destinasyon Çekicilik Unsurlarının Analizi: “Turkey Home” Örneği

Öz

Destinasyon çekicilik unsurları turizm endüstrisinde rekabet avantajı elde etmede etkili faktörlerdir. Bu sebeple ülkeler destinasyon çekiciliklerini uluslararası alanda potansiyel ziyaretçilere tanıtmaya çalışmaktadırlar. Bu amaçla ülkeler tarafından kullanılan en etkili araçlardan biri de çevrimiçi seyahat rehberleridir. Bu araştırmanın amacı, çevrimiçi seyahat rehberlerinde destinasyonlar hakkındaki tanıtım bilgilerinde destinasyon çekicilik unsurlarını analiz ederek betimsel bilgiler elde etmektir. Doküman analizi tekniği kullanılarak Turkey Home internet sitesinden destinasyon bilgileri elde edilmiştir. Verilerin analizinde QDA Miner nitel veri analiz programından yararlanılmıştır. Araştırma sonuçlarına göre, şehrin tarihi, tarihi yapılar ve tabii güzellikler, tanıtım bilgilerinde en çok yer alan destinasyon çekicilik unsurlarıdır. Bununla birlikte kültür-sanat etkinlikleri, iklim, temiz hava, bitki örtüsü, ulaşım olanakları ve turist danışma ofisleri gibi çekicilik unsurlarına ilişkin bilgilerin hiçbir destinasyonda bulunmadığı tespit edilmiştir.

Anahtar Kelimeler: Çevrimiçi Seyahat Rehberleri, Turizm Endüstrisi, Destinasyon Çekicilikleri, İçerik Analizi
Analysis of Destination Attractiveness Factors in Online Travel Guides: The Case of "Home Turkey"

Abstract

Destination attractiveness are effective factors to gain competitive advantage in tourism industry. Therefore, countries try to promoting destination attractiveness to potential visitors in the international area. One of the most effective tools that is used in line with this purpose is online travel guides. The aim of this research is to analyse destination attractiveness factors in the online travel guides and obtain descriptive information. Destination information was obtained from Turkey Home website by using document analysis technique. QDA Miner qualitative data analysis software was used to analyse collected data. According to research results, the most used destination attractiveness factors are history of city, historic buildings and natural beauties. On the other hand, it's determined that there is not information about destination attractiveness factors like cultural and art activities, climate, fresh air, flora, transportation opportunities and tourist information offices does not exist in any destination.

Keywords: Online Travel Guides, Tourism Industry, Destination Attractiveness, Content Analysis

\section{Giriş}

Turizm endüstrisi, ekonomiye sağladığı olumlu katkılar, yarattığı istihdam etkisi, ülke ve bölgelerin kalkınmasında oynadığı rol ve sosyo-kültürel etkileri bakımından önemi giderek artan bir faaliyet alanı olarak dikkat çekmektedir. Ülkelerin birbirileriyle yoğun bir rekabet içerisinde oldukları turizm endüstrisinde turist varış noktaları, diğer bir ifade ile destinasyonlar rekabet avantajı elde etmede önemli bir belirleyici unsur olarak ortaya çıkmaktadır. Bu bakımdan destinasyon kavramını, turizm endüstrisinde üzerinde önemle durulması gereken kavramlardan biri olarak değerlendirmek mümkündür.

Kişilerin geçici yer değiştirmeleri sonucu gerçekleşen turizm faaliyetlerinde sürekli yaşanılan yer dışında bir başka destinasyonun ziyaret edilmesi söz konusudur. Seyahat faaliyetinin gerçekleştirileceği destinasyonlar, sahip oldukları bazı çekicilikler ile tercih sebebi olmakta, ziyaretçiler için bir çekim unsuru oluşturmaktadır. Aynı zamanda, destinasyonların sahip olduğu kendine özgü çekicilik unsurları diğer destinasyonlarla rekabette avantaj elde etmelerini sağlayabilmektedir. Bu nedenle destinasyon kavramıyla birlikte destinasyon çekiciliği kavramı da ilgili alanyazında araştırmacılar arasında (Formica ve Uysal, 2006; Prebezac ve Mikulic,

${ }^{1}$ Dr. Öğr. Üyesi, Zonguldak Bülent Ecevit Üniversitesi, Kdz. Ereğli Turizm Fakültesi, Turizm İşletmeciliği Bölümü.

fatih.ercan@beun.edu.tr, Yazar ORCID bilgisi: https://orcid.org/0000-0001-6469-3000 
2008; Vengesayi vd., 2009; Henderson, 2010) ilgi çeken diğer bir önemli kavram olarak görülmektedir.

Vengesayi vd.(2009) tarafından 275 yerli ve yabancı turist üzerinde gerçekleştirilen araştırmanın sonuçlarına göre, destinasyonların sahip olduğu kültürel, doğal, tarihi, mimari, yemek kültürü, geleneksel sanatlar gibi destinasyon çekicilik unsurları çekiciliğin en önemli belirleyicileridir. Destinasyonlardaki yol, ulaşım, haberleşme olanakları gibi destek hizmetler ve yerel halkın turistlere yönelik tutumu gibi faktörler ise çekicilikte ikincil belirleyiciler olmaktadır. Yazarların burada, destinasyon çekiciliğinde, destinasyona özgü kültürel, doğal, tarihi ve diğer çekicilik unsurlarının önemine vurgu yaptıkları görülmektedir. Uluslararası turizm pazarında rekabet avantajı elde etmenin destinasyonların sahip olduğu turistik çekicilik unsurlarının kalitesi ile mümkün olacağını belirten Blazeska vd. (2015), destinasyon çekicilik unsurlarının turist memnuniyeti ya da memnuniyetsizliğinde etkili olduğunu belirtmektedirler. Yazarların Makedonya'ya gelen turistlerin seyahat motiflerini tespit etmeye yönelik gerçekleştirdikleri araştırma sonuçlarına göre, iklim, tabii güzellikler, yemekler en önemli seyahat motifleriyken, eğlence etkinlikleri, gece hayatı, dinlenme ve spor etkinlikleri önem derecesi daha düşük seyahat motifleridir.

Şen Demir (2010), Dalyan'a özgü çekici faktörlerin turistlerin tatil yeri seçimindeki etkisini belirlemeye yönelik araştırmasında, tarihi ve doğal çekicilikler, rekreasyonel çekicilikler, konaklama ve ulaşım olanakları ve sosyo-kültürel değerlere ilişkin destinasyon çekicilik unsurlarının tamamının turistlerin destinasyon seçim kararları üzerinde önemli derecede etkisinin olduğu sonucuna ulaşmıştır. Yazar burada, turistlerin destinasyon seçimi ve tatil satın alma kararlarında destinasyon çekicilik unsurlarının önemine vurgu yapmaktadır. İlgili alanyazında destinasyon çekicilik unsurlarının analizine yönelik diğer araştırmalarda destinasyon çekicilik unsurlarının tespitinde anket tekniği ile birlikte son yıllarda çevrimiçi yazılı dokümanların (internet siteleri, kurumsal sosyal medya hesapları, sosyal medya kullanıcı yorumları, vb.) analizi ile veri toplamanın da yaygın bir şekilde kullanılmaya başlandığı (Formica ve Uysal, 2006; Henderson, 2010; Gu vd., 2016) görülmektedir.

Günümüzde ülkeler, destinasyon bazında ulusal ve uluslararası alanda tanıtım faaliyetlerine daha fazla önem vermekte, çeşitli iletişim kanallarını bu amaçla kullanmaktadırlar. Tanıtım amaçlı oluşturulan çevrimiçi seyahat rehberleri, potansiyel ziyaretçilere ulaşmada en etkili yöntemlerden biri olarak dikkat çekmektedir. Bu çevrimiçi kaynaklarda, destinasyonlara ilişkin ulaşım, konum, vb. genel bilgilerle birlikte destinasyonda yer alan çeşitli çekicilik unsurlarına yer verilmektedir. Dolayısıyla, çevrimiçi seyahat rehberlerini, destinasyon çekicilik unsurlarının yer aldığı önemli birer kaynak olarak nitelendirmek mümkündür. Bu bağlamda bu araştırmanın amacı, çevrimiçi seyahat rehberlerindeki destinasyon tanıtım bilgilerinde yer alan destinasyon çekicilik unsurlarını analiz ederek betimsel bilgiler elde etmektir. Destinasyon çekicilik unsurları sınıflandırılarak, destinasyon bilgilerinde hangi çekicilik unsurlarına daha fazla yer verildiği, çekicilik unsurlarının destinasyon bazında dağılımı ve eksik unsurların ortaya konması, potansiyel ziyaretçilere ulaşma ve destinasyona yönelik çekiciliğin artırılması açısından önem taşımaktadır.

\section{Kavramsal Çerçeve}

\subsection{Destinasyon ve Destinasyon Çekiciliği Kavramları}

Illetişim ve ulaşım teknolojilerinde yaşanan hızlı gelişmelerin, kişilerin sürekli yaşadıkları yerler dışındaki farkı bölgelerden haberdar olmasını ve seyahatlerini kolaylaştırdığı görülmektedir. Bu nedenle dünya üzerindeki herhangi bir bölgeye gerçekleşen turistik seyahatler bura- 
ların birer turistik destinasyona dönüşmesini sağlamakta ve turizm endüstrisinde destinasyon kavramının önemini artırmaktadır. Destinasyon kavramı, Türk Dil Kurumu (TDK) tarafından kısaca "varılacak olan yer" olarak tanımlanmaktadır. Turizm destinasyonu, turizm endüstrisinde temel kavramlardan biri olmakla birlikte araştırmacı ve uygulamacılar arasında bu kavramın tanımına ilişkin bir fikir birliği olmadığı görülmektedir (Saraniemi ve Kylanen, 2011: 133). Bununla birlikte destinasyon kavramının turizm alanında, turizm merkezlerini belirtmek amacıyla kullanıldığı dikkat çekmektedir. Turizm bölgelerini destinasyon olarak niteleyen Kozak vd. (2012: 45-46), bir ada, kasaba gibi çok iyi tanımlanmış coğrafi alanların turizm bölgelerini, diğer bir ifade ile destinasyonları oluşturduğunu belirtmektedirler. Yazarlar, turizm bölgesi, dolayısıyla destinasyon kavramını geniş bir şekilde şöyle tanımlamaktadırlar:

"Turizm bölgesi, ülke bütününden küçük ve ülke içindeki pek çok kentten büyük, insan beyninde belli bir imaja sahip markalaşmış ulusal bir alan ve önemli turizm çekicilikleri, çekim merkezleri ve festivaller, karnavallar gibi çeşitli etkinlikleri, bölge içinde kurulmuş iyi bir ulaşım ağına, gelişim potansiyeline, dahili ulaşım ağıyla bağlantılı bölgeler arası ve ülke düzeyinde ulaşım olanaklarına ve turizm tesislerinin gelişimi için yeterli coğrafi alana sahip bir bölgedir."

Turizm terimleri sözlüğünde turizm destinasyonu, turizm faaliyetlerinin ana konumunda bulunan, turistlerin zamanlarının çoğunu geçirdikleri, harcama yaptıkları ülkeler, bölgeler, kasabalar ve turistleri çeken diğer alanlar olarak tanımlanmaktadır. Destinasyonlar aynı zamanda, turizmin ekonomik, sosyal, fiziksel etkilerinin gerçekleştiği turistik çekicilikler, konaklama ve diğer turist faaliyetlerinin temel odak noktasını oluşturmaktadır (Medlik, 2003: 165). Bu tanımlamalardan hareketle destinasyon kavramını, turizm faaliyetinin gerçekleşmesi için gerekli turistik çekim unsurlarına ve ulaşılabilirliğe sahip, turizm faaliyetlerinin odak noktasını oluşturan bir ülke, bölge, şehir ya da kasaba gibi yerleşim birimleri olarak tanımlamak mümkündür.

Saraniemi ve Kylanen (2011: 133), bir turizm destinasyonunun, ortak deneyim oluşturmada birbirileriyle etkileşim içinde olan işletmeler, kamu kurumları, yerel halk ve ziyaretçiler gibi farklı paydaşların faaliyette bulundukları yer olarak nitelendirilebileceğini belirtmektedirler. Yazarlara göre, turizmde destinasyon kavramının derinlemesine incelenerek tanımlanması, destinasyondaki çekicilik unsurlarının başarılı bir şekilde pazarlanması açısından oldukça önem taşımaktadır. Dolayısıyla, destinasyon çekiciliği, destinasyon kavramıyla birlikte ele alınan, ilgili alanyazında (Şen Demir, 2010; Henderson, 2010; Kresic ve Prebezac, 2011; Blazeska vd., 2015; Gu vd., 2016) sıklıkla üzerinde durulan önemli bir kavram olarak dikkat çekmektedir.

Kozak vd. (2012: 42), çekiciliğin turizm ürününün en önemli unsurlarından biri olduğunu, turistin seyahat etmek istediği bir yeri, diğer bir yere tercih etmesini etkileyen unsurlar olarak açıklanabileceğini belirtmektedirler. Kutvan ve Kutvan (2013: 160), çekiciliğin turizm talebinin temelini oluşturduğunu belirterek, destinasyon çekiciliğini genel olarak tercihlerin ve isteklerin belli bir yöre üstünde yoğunlaşma derecesi olarak tanımlamaktadırlar. Formica ve Uysal (2006: 418-419), bir destinasyonun, turizm endüstrisinde belirli bir çekicilik gücüne sahip tedarikçi unsur olduğunu, destinasyon çekiciliğinin sahip olunan kaynaklar ve bu kaynaklara yönelik talebin bir fonksiyonu olarak ortaya çıktığını belirtmektedirler. Şen Demir (2010: 1042), çekici faktörlerin destinasyona ilişkin özellikleri ifade ettiğini belirterek, tarihi ve doğal güzellikler, kentsel mimari doku, konaklama ve ulaştırma olanakları gibi unsurları destinasyon çekiciliği kapsamında değerlendirmektedir. Bir yörenin sahip olduğu doğal güzellikler ve kaynaklar, tarihi, kültürel değerler, turistik işletmeler, rekreasyonel olanaklar gibi unsurların bir araya gelerek oluşturduğu, bir yörenin ziyaret edilmesini teşvik eden unsurlar destinasyon 
çekiciliğini meydana getirmektedir. Bu sebeple, turistik merkezlerin destinasyon çekicilik unsurlarının iyi analiz edilmesi, destinasyonun pazarlanması ve tanıtımında bu unsurların vurgulanması önemli bir husus olarak değerlendirilebilir.

\subsection{Destinasyon Çekicilik Unsurları}

Turizm endüstrisinin ülkelerin gelişiminde önemli bir rol oynadığı, bu sebeple turizm destinasyonlarının kalitesi ve çekiciliklerinin artırılması gerekliliği kritik öneme sahip hususlardır. Turizm endüstrisinden gelecekte daha fazla pay alacak olan ülkelerin, dünya genelindeki turistlerin büyük bir bölümünü kendine çekecek destinasyon çekiciliklerine sahip ve bunları en iyi şekilde kullanan ülkeler olacağı öngörülmektedir (Blazeska vd., 2015: 341). Kresic ve Prebezac'a (2011) göre, rekabetin her geçen gün giderek daha da arttığı küresel turizm pazarında destinasyonlar, rekabetçi avantajlarını korumak ve sürdürebilmek için çekicilik unsurlarını yenileme, iyileştirme ve artırma baskısı ile karşı karşıyadırlar. Yazarlar, turistik çekicilik unsurlarının destinasyon rekabet gücünün önemli bir belirleyicisi olduğunu vurgulamakta, destinasyonlarda uzun dönemli sürdürülebilir bir büyüme ve gelişimin sağlanmasında destinasyon çekicilik unsurlarının önemine dikkat çekmektedirler. Destinasyonların rekabette avantajlı bir konum elde etmelerinde ve bunu sürdürebilmelerinde sahip oldukları çekicilik unsurlarının ön planda olması, güçlü ve fark yaratan çekici yönlerinin vurgulanmasını kritik öneme sahip faktörler olarak ifade etmek mümkündür.

Turistlerin beklentilerini, istek ve ihtiyaçlarını karşılamada daha etkin olan destinasyonların rakipleri karşısında rekabet avantajı elde edeceğini vurgulayan Neto vd. (2019: 2), destinasyon niteliklerinin, sahip olduğu çekicilik unsurlarının destinasyon rekabet gücünü belirleyen en önemli faktörler olduğunu belirtmektedirler. Bir destinasyonun sahip olduğu niteliklerin, algılanan destinasyon çekiciliğinin ana unsuru olduğunu belirten Prebezac ve Mikulic (2008: 173175), Hırvatistan ve Hawaii'de algılanan destinasyon imajı ve çekicilik unsurlarının belirlenmesine yönelik bir araştırma gerçekleştirmişlerdir. Bu araştırmada, güzel manzara, ulaşım olanakları, dinlendirici faaliyetler, iklim koşulları, konaklama imkânları, restoran ve kafeler, spor etkinlikleri, yemekler, doğal çekicilikler, alışveriş olanakları, gece hayatı, kültürel/tarihi değerler, yerel halkın misafirperverliği, sahiller ve denizler, turist bilgilendirme noktaları gibi unsurların destinasyonların çekicilik unsurlarının tespitinde yazarlar tarafından kullanılan unsurlar olduğu görülmektedir. Singapur'un sahip olduğu destinasyon çekicilik unsurlarına yönelik tanıtım faaliyetlerinin etkinliğinin, ülkenin diğer destinasyonlara karşı rekabet avantajı elde etmesinde önemli bir faktör olduğunu belirten Henderson (2010: 251-252), ülkenin kültürel yapısı, doğal çekicilikleri, alışveriş olanakları, spor organizasyonları, turistik altyapı, ulaşım olanakları, konaklama işletmeleri, yiyecek içecek işletmeleri, parklar, eğlence etkinlikleri, yerel yaşantının ülkenin önemli destinasyon çekicilik unsurlarını meydana getirdiğini vurgulamaktadır. Yazar, bu unsurların destinasyonların sürdürülebilir gelişiminde önemli bir rol oynadığını ve çekiciliğin artırılmasında uluslararası alanda tanıtımlarının gerçekleştirilmesinin gerekli olduğunu belirtmektedir.

Turizm arzının nitelikleri dikkate alındığında bir ülkenin, yörenin sahip olduğu en önemli çekicilik unsurlarının fiziksel faktörler olduğunu belirten Kutvan ve Kutvan'a (2013: 161) göre, kıyı alanları olan deniz ve sahiller, doğal bitki örtüsü, manzara, tarihi değerler, doğal kaynaklar, yörenin iklimi, mimari yapı, geleneksel yapı, şenlik ve festivaller gibi eğlence etkinlikleri, yerel yaşantı, tarihi değerler, kültürel değerler, tarihi yapılar, ulaşım, kaplıcalar, piknik alanları, doğal çekiciliğe sahip alanlar, parklar, tiyatrolar, sanat galerileri gibi kültürel çekicilik unsurları, müzeler, alışveriş olanakları, konaklama ve yiyecek içecek işletmeleri bir destinasyondaki belli 
başlı çekicilik unsurlarıdır. Illgili alanyazında, destinasyon çekiciliğini kapsayan çalışmalar ve bu çalışmalarda yer alan destinasyon çekicilik unsurları Tablo 1'de gösterilmektedir.

Tablo 1: Destinasyon Çekiciliğine Yönelik Çalışmalar ve Çekicilik Unsurları

\begin{tabular}{|c|c|c|c|}
\hline Yazar(lar) & Tarih & Başlık & Destinasyon Çekicilik Unsurları \\
\hline $\begin{array}{l}\text { Formica, S. } \\
\text { ve Uysal, M. }\end{array}$ & 2006 & $\begin{array}{l}\text { Destination Attractive- } \\
\text { ness Based on Supply } \\
\text { and Demand Evalua- } \\
\text { tions: An Analytical } \\
\text { Framework }\end{array}$ & $\begin{array}{l}\text { Otel İşletmeleri, Yiyecek İçecek İşletmeleri, Hediyelik Eşya } \\
\text { Mağazaları, Tarihi Yapılar, Müzeler, Festivaller, Dinlendirici } \\
\text { Faaliyetler, Park Alanları, Doğa Aktiviteleri, Rekreasyonel } \\
\text { Olanaklar }\end{array}$ \\
\hline $\begin{array}{l}\text { Prebezac, D. } \\
\text { ve Mikulic, j. }\end{array}$ & 2008 & $\begin{array}{l}\text { Destination Image and } \\
\text { Key Drivers of Percie- } \\
\text { ved Destination Attrac- } \\
\text { tiveness }\end{array}$ & $\begin{array}{l}\text { Güzel Manzara, Ulaşım Olanakları, Dinlendirici Faaliyetler, } \\
\text { İklim Koşulları, Konaklama İmkânları, Restoran ve Kafeler, } \\
\text { Spor Etkinlikleri, Yemekler, Doğal Çekicilikler, Alışveriş Ola- } \\
\text { nakları, Gece Hayatı, Kültürel/Tarihi Değerler, Yerel Halkın } \\
\text { Misafirperverliği, Sahiller Ve Denizler, Turist Bilgilendirme } \\
\text { Noktaları }\end{array}$ \\
\hline $\begin{array}{l}\text { Henderson, } \\
\text { J. C. }\end{array}$ & 2010 & $\begin{array}{l}\text { New Visitor Attractions } \\
\text { in Singapore and } \\
\text { Sustainable Destination } \\
\text { Development }\end{array}$ & $\begin{array}{l}\text { Kültürel Yapı, Doğal Çekicilikler, Alışveriş Olanakları, Spor } \\
\text { Organizasyonları, Turistik Altyapı, Ulaşım Olanakları, Konak- } \\
\text { lama İşletmeleri, Yiyecek İçecek İşletmeleri, Parklar, Eğlence } \\
\text { Etkinlikleri, Yerel Halk ve Yaşantı }\end{array}$ \\
\hline $\begin{array}{l}\text { Kutvan, A. B. } \\
\text { ve Kutvan, S. } \\
\text { A. }\end{array}$ & 2013 & $\begin{array}{l}\text { Turizm Planlamasında } \\
\text { Destinasyon Çekicilikle- } \\
\text { rinin Ölçümü: Bir } \\
\text { Yöntem Yaklaşımı }\end{array}$ & $\begin{array}{l}\text { Deniz ve Sahiller, Doğal Bitki Örtüsü, Manzara, Tarihi Değer- } \\
\text { ler, Doğal Kaynaklar, Yörenin İklimi, Mimari Yapı, Geleneksel } \\
\text { Yapı, Şenlik ve Festivaller gibi Eğlence Etkinlikleri, Yerel } \\
\text { Yaşantı, Tarihi Değerler, Kültürel Değerler, Tarihi Yapılar, } \\
\text { Ulaşım, Kaplıcalar, Piknik Alanları, Doğal Çekiciliğe Sahip } \\
\text { Alanlar, Parklar, Tiyatrolar, Sanat Galerileri gibi Kültürel } \\
\text { Çekicilik Unsurları, Müzeler, Alışveriş Olanakları, Konaklama } \\
\text { ve Yiyecek İçecek İşletmeleri }\end{array}$ \\
\hline
\end{tabular}

Kaynak: Yazar tarafından derlenmiştir.

Tablo 1'deki veriler incelendiğinde, destinasyon çekicilik unsurlarının ülke, bölge veya yörenin karakteristik özelliklerine göre farklılıklar gösterebildiği, bununla birlikte kültürel ve tarihi çekicilikler, doğal çekicilikler, rekreasyonel çekicilikler, turistik çekicilik temaları ve bu temalar altındaki unsurların bir destinasyonun çekiciliğini oluşturan ortak faktörler olduğu ifade edilebilir. Bu sebeple, destinasyonların karakteristik özellikleri dikkate alınarak çekicilik unsurlarının ortaya konması ve bu unsurların çeşitli iletişim araçları vasıtasıyla farklı şekillerde potansiyel turistlere aktarılmasının destinasyon tanıtım ve pazarlama faaliyetlerinin başarısı açısından kritik bir öneme sahip olduğu düşünülebilir.

\section{3. Çevrimiçi Seyahat Rehberleri}

Turizm endüstrisi günümüzde ülkelerin ekonomilerine önemli ölçüde katkı sağlayan, toplumları birbirine yakınlaştıran önemli bir araç konumundadır. Bu sebeple destinasyonlar, sahip oldukları çeşitli değerleri ulusal ve uluslararası alanda tanıtma ve destinasyona yönelik çekiciliği artırma çabasındadırlar. Diğer tüm alanlarda olduğu gibi gelişen internet teknolojilerinin, çeşitli amaç ve şekillerde turizm endüstrisinde yoğun bir biçimde kullanıldığı görülmektedir. Ulusal ve uluslararası alanda gerek turizm işletmeleri, gerekse kamu kurumları tarafından kullanılan kurumsal internet siteleri, potansiyel turistlere ulaşma ve tanıtımda en etkili iletişim yöntemlerinden biri olarak dikkat çekmektedir.

Kişiler seyahatlerini planlamada ve destinasyon seçiminde bilgi kaynağı olarak interneti kullanmakta, buradan elde ettikleri bilgilere göre seyahat deneyimini gerçekleştirecekleri destinasyonu belirleyebilmektedirler. Sarı ve Kozak (2005: 249), turist çeken ülkeler ve tanıtımdan sorumlu ulusal turizm örgütlerinin, artan rekabet ortamında ulusal bazda pazar paylarının korunması için çağdaş teknolojilerden yararlanılması gerektiğine değinmekte, bu hususta 
modern bilgi iletişim teknolojilerinin kullanılmasının önemine vurgu yapmaktadırlar. Yazarlar, destinasyonların tüketicilere doğrudan tanıtımında internetin önemine dikkat çekmekte, ulusal turizm örgütlerince bu amaçla oluşturulmuş bir internet sitesinde destinasyonla ilgili genel bilgilerle birlikte çekicilik unsurlarının da ayrıntılı bir şekilde yer alması gerektiğini belirtmektedirler.

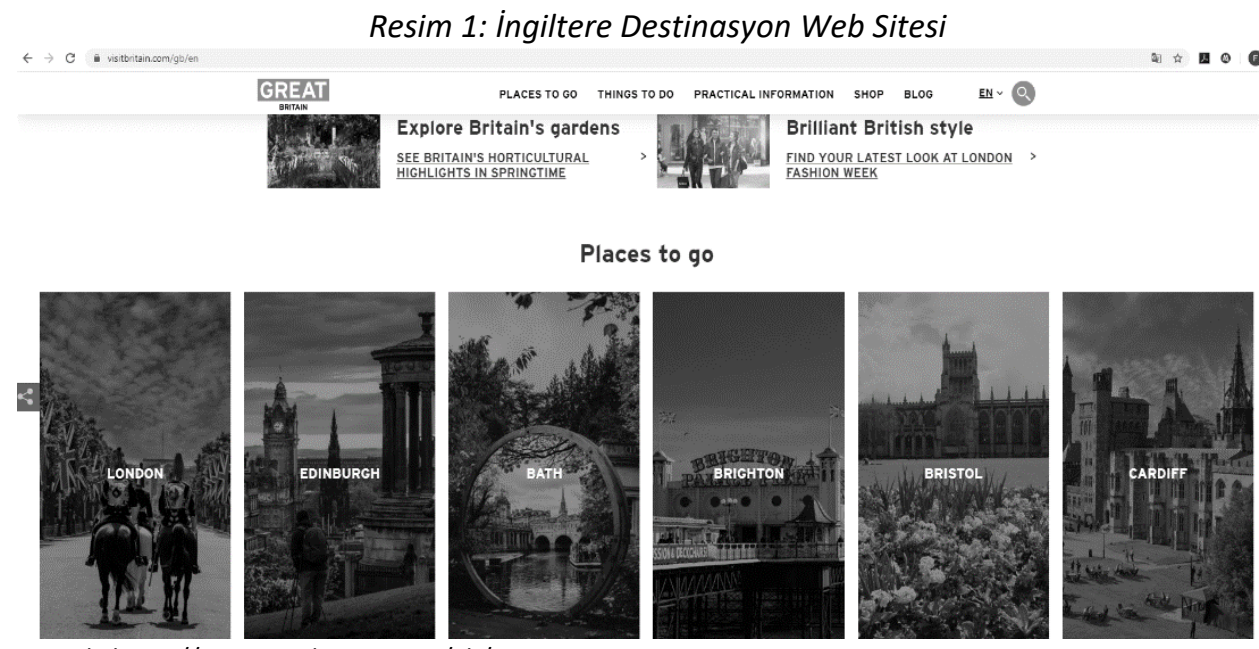

Kaynak: https://www.visitbritain.com/gb/en

Son yıllarda ülkemizde Kültür ve Turizm Bakanlığı ve ilgili kamu kurumları nezdinde ülke tanıtımına ilişkin faaliyetlerde internet sitelerinden giderek daha fazla yararlanıldığı görülmektedir. Ülkemizin sahip olduğu turistik değerlerin ve destinasyonların, oluşturulan resmi internet sitelerinde uluslararası alanda etkin bir şekilde tanıtımının yapılması yönünde girişimler mevcuttur. Bu alanda son zamanlarda kullanılan en önemli internet sitelerinden biri de "Turkey Home" sayfasıdır. Türkiye'nin resmi seyahat rehberi olarak Kültür ve Turizm Bakanlığı tarafından oluşturulan internet sitesinde, Türkiye'nin kültürel, tarihi ve doğal çekicilikleri hakkında ülke, bölge ve şehir bazında İngilizce olarak bilgiler sunulmaktadır. Çekicilik unsurları burada her destinasyon için detaylı bir şekilde aktarılmaktadır. Bunlarla birlikte, "Turkey Home" internet sitesinde fotoğraf, video, haritalar gibi görsel bilgiler de sunulmakta, site ziyaretçileri "Turkey Home" sosyal medya sayfalarına yönlendirilmektedir.

\section{4. Çevrimiçi Seyahat Rehberlerinin Destinasyonlar Açısından Önemi}

Turizm hizmetlerinin soyut olması, satın almadan önce deneme olanağının bulunmaması gibi kendine has özellikleri turizm endüstrisinde seyahat öncesi bilgi arama ve edinmenin önemini daha çok arttırmaktadır. İnternet günümüzde, seyahat öncesi bilgi arama, turistik ürün/hizmet çeşitleri ve kalitesi ile destinasyonlar hakkında bilgi edinmede önemli bir araç konumundadır. İnternet kullanımının kişiler arasında yaygınlaşması, farklı çevrimiçi bilgi ve iletişim araçlarının ortaya çıkmasına neden olmaktadır. Seyahat ve turizmle ilgili basılı kitapçıklar, broşürler, dergiler gibi tanıtım materyallerinin günümüzde yerini çevrimiçi bilgi kaynaklarına bıraktığı, dijital teknolojilerin bu alanda da kullanımının yaygınlaştığı dikkat çekmektedir. Ulaşım, konaklama, yiyecek içecek alanında sunulan hizmetlerle birlikte destinasyonlara ilişkin bilgilere de çevrimiçi rehberlerden istenilen yerde ve zamanda, kolay ve hızlı bir şekilde ulaşılabilmektedir.

Destinasyonlar günümüzde mevcut ve potansiyel ziyaretçilerine internet üzerinden daha etkili bir şekilde ulaşabilmekte, pazarlama iletişimi faaliyetlerini gerçekleştirmekte ve desti- 
nasyon pazarlama faaliyetleri çevrimiçi ortamda yürütülmektedir. Kişilerin destinasyon hakkında olumlu/olumsuz tutumlarının oluşumunda, seyahat öncesinde destinasyon imajı oluşumunda ve destinasyona ziyaretçi çekmede çevrimiçi ortamdaki araçlarda gerçekleştirilen tanıtım ve pazarlama faaliyetleri kritik bir öneme sahiptir (Alcantara-Pilar vd., 2018:308; Lever, Shen ve Joppe, 2019:1). Çevrimiçi seyahat rehberleri, bir destinasyonun sahip olduğu çekicilik unsurlarının tanıtılması ve kişilerin zihninde bir bütün olarak destinasyon imajı algısı oluşumunda etkili bir araç olarak görülmekte ve destinasyon yönetiminde etkinliği artırmaktadır (Agusti, 2018: 113). Jimenez-Barreto vd.'ne (2019: 348) göre, destinasyonlar hakkında bilgi arama faaliyetlerinde çevrimiçi ortamların kullanım sıklığı arttıkça, destinasyon pazarlama örgütlerinin çevrimiçi ortamda olumlu destinasyon marka deneyimi oluşturmaları da önemli bir gereklilik haline gelmektedir. Yazarlar, destinasyonların internet tabanlı uygulamalarda ve bilgi kaynaklarında çevrimiçi destinasyon markası oluşturmalarının önemini vurgulamakta, destinasyonların rekabet avantajı elde etmelerinde resmi destinasyon tanıtım web sitelerinin ve çevrimiçi seyahat rehberlerinin kritik rollerinden bahsetmektedirler.

Turizm destinasyonlarının resmi web siteleri ve seyahat rehberleri gibi çevrimiçi ortamlarda tanıtımı, dünya genelinde sıkça uygulanan bir iletişim ve destinasyon pazarlama yöntemi olarak belirtilmekte, bununla birlikte destinasyon bilinirliğinin artırılması, olumlu bir destinasyon imajının geliştirilmesi ve rakip destinasyonlar karşısında rekabet avantajı elde edilmesinde anahtar bir faktör olarak gösterilmektedir (Vijoli ve Marinescu, 2016: 153). Turizm destinasyonlarının mevcut ve potansiyel ziyaretçilerin zihninde konumlanması, diğer destinasyonlardan farklı olarak algılanmasının sağlanması, destinasyona özgü çekicilik unsurlarının ön plana çıkarılması, destinasyona seyahat kararının verilmesinde çevrimiçi seyahat rehberleri önemli bir araç olarak değerlendirilmektedir (Luigi, Iuliana ve Alma, 2014: 59-60; Iglesias-Sanchez, Correia ve Jambrino-Maldonado, 2019: 36-38).

\section{Araştırmanın Yöntemi}

Çevrimiçi seyahat rehberlerindeki destinasyon bilgilerinde yer alan destinasyon çekicilik unsurlarının analizinin amaçlandığı bu araştırmada, T.C. Kültür ve Turizm Bakanlığı tarafından oluşturulan, Türkiye'nin resmi çevrimiçi seyahat rehberi "Turkey Home" isimli internet sitesinde (https://hometurkey.com/en/) verilen destinasyon tanıtım metinlerinden yararlanılmıştır. "Turkey Home" internet sitesi, destinasyonları bölgelere göre ayırmakta ve destinasyonda yer alan çekicilikler hakkında İngilizce tanıtıcı bilgiler sunarak ülkemizin uluslararası alanda tanıtımını gerçekleştirmektedir. Bu araştırmada, yerli ve yabancı turistler tarafından yoğun bir şekilde ziyaret edilen, Türkiye'nin popüler tatil destinasyonlarının yer aldığı Ege bölgesindeki, "Turkey Home" internet sitesinde hakkında bilgi verilen altı destinasyon (İzmir, Muğla, Aydın, Denizli, Pamukkale, Bergama) örneklem olarak seçilmiş ve içerik analizine tabi tutulmuştur. Sahip oldukları zengin doğal, kültürel, tarihi ve turistik çekicilik unsurları, araştırmada bu altı destinasyonun seçiminde önemli bir etkendir.

Araştırmada veri toplama aracı olarak doküman incelemesi tekniği kullanılmıştır. Nitel araştırmalarda kullanılan bu teknik, araştırılması hedeflenen olay veya olgular hakkında bilgi içeren yazılı materyallerin analizini kapsamaktadır (Şimşek, 2009: 42-43). Doküman incelemesi ile "Turkey Home" internet sitesinde Ege Bölgesindeki altı destinasyon hakkındaki tanıtıcı bilgilerden veriler elde edilmiş, araştırma amacına uygun bir biçimde toplanan bu veriler içerik analizi yöntemi ile analiz edilmiştir. İçerik çözümlemesi olarak da isimlendirilen bu yöntem, yazılı, görsel veya işitsel bir mesajı oluşturan öğelerin araştırma amacı doğrultusunda değerlendirilmesi eylemlerini kapsayan bir veri analiz tekniğidir (Ural ve Kılıç, 2013: 65). QDA Miner 
nitel veri analiz programına aktarılan veriler, ilgili alanyazın taraması (Formica ve Uysal, 2006; Prebezac ve Mikulic, 2008; Şen Demir, 2010; Henderson, 2010; Kutvan ve Kutvan, 2013) ve internet sitesi içeriklerinin incelenmesi sonucu oluşturulan destinasyon çekicilik unsurlarına ilişkin tema ve kodlara göre sınıflandırımıştır. Daha sonra, destinasyon çekicilik unsurlarına ilişkin toplam kodlama sayıları ve yüzdeleri, destinasyonlara göre kodların dağılımları, temalar altında belirlenen kodların destinasyonlara göre dağılım yüzdeleri, destinasyon çekicilik unsurlarına ilişkin benzerlik oranlarının analizi gerçekleştirilmiştir.

Destinasyon çekicilik unsurlarının tema ve kodlara göre sınıflandırılması uygulamasının güvenilirliğinin sağlanmasında kodlayıcılar arası uyum analizi gerçekleştirilmiştir. Bu yöntemde, iki ya da daha fazla araştırmacı aynı dokümandaki bilgileri farklı zamanlarda aynı kodları kullanarak kodlamaktadır. Kodlayıcıların anlaşmaya vardıkları uyumlu kodlamaların toplamı, uyumlu ve uyumlu olmayan toplam kodlama sayısına bölünerek kodlama güvenilirliği hesaplanmaktır.

Tablo 2: Kodlayıcılar Arası Uyum Değerlendirmesi

\begin{tabular}{lcccc}
\hline & Kodlanmayan Bölüm Uyumu & Kodlama Uyumu & $\begin{array}{c}\text { Kodlama } \\
\text { Uyuşmazlığı }\end{array}$ & $\begin{array}{c}\text { Uyuşma } \\
\text { Yüzdesi }\end{array}$ \\
\hline \hline Toplam & 9976 & 100 & 346 & $\% 96,7$ \\
\hline
\end{tabular}

Bu araştırmada, kodlama güvenilirliğinin sağlanmasında, destinasyon çekicilik unsurlarına ilişkin araştırmacı tarafından incelenip kodlanan metinler başka bir uzman tarafından farklı bir zamanda yeniden kodlanmıştır. Uzman tarafından yapılan kodlamada destinasyon çekicilik unsurlarına ilişkin araştırmacı tarafından önceden belirlenen aynı tema ve kodlar kullanılmıştır. Daha sonra QDA Miner nitel araştırma programına aktarılan bu veriler kodlayıcılar arası uyum analizine tabi tutulmuştur. Nitel araştırmalarda güvenilirlik için önerilen formül şu şekildedir (Miles ve Huberman, 1994: 64):

$$
\text { Güvenilirlik }=\frac{\text { Uyuşma Sayısı }}{\text { Toplam Uyuşma Sayısı + Uyuşmazlık Sayısı }}
$$

Analiz sonuçlarına ilişkin Tablo 2'de, kodlanmayan bölüm uyumu (agree absent), incelenen metinlerde herhangi bir kodlama unsurunun olmadığı bölümlere dair uyumu, kodlama uyumu (agree present) incelenen metinlerde uzman ve araştırmacı arasındaki kodlama uyumunu, kodlama uyuşmazlığı (disagree) ise incelenen metinlerdeki kodlama uyuşmazlığını ifade etmektedir. Kodlamalarda araştırmacı ve uzman arasındaki toplam uyum sayısının (kodlanmayan bölüm uyumu + kodlama uyumu) toplam kodlama sayısına bölünmesiyle elde edilen oran uyuşma yüzdesini göstermektedir. Bu araştırmada iki kodlayıcı arasındaki uyum yüzdesi $\% 96,7$ olarak hesaplanmıştır. Bu oran Miles ve Huberman (1994: 64) tarafından önerilen iki kodlayıcı arası minimum uyum oranı olan $\% 90$ 'ın üzerindedir. Dolayısıyla bu araştırmada kodlama güvenilirliğinin yeterli seviyede olduğu görülmektedir.

\section{Araştırmanın Bulguları}

"Turkey Home" internet sitesinde yer alan Ege Bölgesindeki destinasyonlara ilişkin çekicilik unsurlarının tema ve kodlara göre frekans ve yüzde dağılımları Tablo 3'te verilmektedir. Tablo incelendiğinde, en çok kodlanan çekicilik unsurlarının sırasıyla tarihi yapılar (64), şehrin tarihi (51) ve tabii güzellikler (25) olduğu görülmektedir. Tarihi yapılar ve şehrin tarihi çekicilik unsurları araştırma kapsamındaki tüm destinasyonlarda kodlanmışken, tabii güzellikler ise beş destinasyonda kodlanmıştır. Buna karşın kültür-sanat etkinlikleri, temiz hava, iklim, bitki örtüsü, spor etkinlikleri, seyahat işletmeleri, ulaşım olanakları, turist danışma ofisleri gibi çekicilik unsurlarının hiçbir destinasyonda kodlanmadığı, dolayısıyla tanıtım metinlerinde bu çekicilik 
unsurlarına yer verilmediği dikkat çekmektedir. Tabloda yer alan diğer destinasyon çekicilik unsurları içerisinde konaklama işletmeleri (17), deniz ve sahiller (15) ve tarihi eserler (14) en çok kodlanan diğer destinasyon çekicilik unsurları olarak ortaya çıkmaktadır.

Tablo 3: Destinasyon Çekicilik Unsurları Kodlanma Sayıları ve Destinasyonlara Göre Dağılımlar

\begin{tabular}{|c|c|c|c|c|c|}
\hline Temalar & Kodlar & $\begin{array}{l}\text { Kodlanma } \\
\text { Sayısı }\end{array}$ & $\begin{array}{l}\text { Kodlanma } \\
\text { Yüzdesi }\end{array}$ & $\begin{array}{c}\text { Destinasyon } \\
\text { Sayısı }\end{array}$ & Destinasyon Yüzdesi \\
\hline \multirow{9}{*}{ 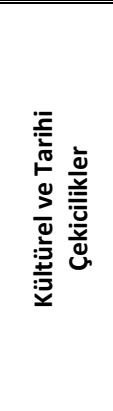 } & Kültür-Sanat Etkinlikleri & - & - & - & - \\
\hline & Şehir Mimarisi & 13 & $\% 4,2$ & 5 & $\% 83,3$ \\
\hline & Geleneksel Sanatlar & 5 & $\% 1,6$ & 3 & $\% 50$ \\
\hline & Yerel Yaşantı & 1 & $\% 0,3$ & 1 & $\% 16,7$ \\
\hline & Şehrin Tarihi & 51 & $\% 16,6$ & 6 & $\% 100$ \\
\hline & Tarihi Eserler & 14 & $\% 4,6$ & 5 & $\% 83,3$ \\
\hline & Müzeler & 9 & $\% 2,9$ & 6 & $\% 100$ \\
\hline & Tarihi Yapılar & 64 & $\% 20,8$ & 6 & $\% 100$ \\
\hline & Yemek Kültürü & 4 & $\% 1,3$ & 3 & $\% 50$ \\
\hline \multirow{12}{*}{ 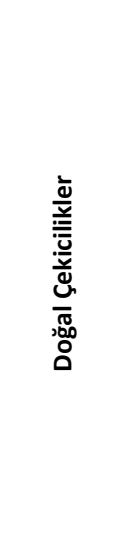 } & Temiz Hava & - & - & - & - \\
\hline & Deniz ve Sahiller & 15 & $\% 4,9$ & 3 & $\% 50$ \\
\hline & Göller & 3 & $\% 1$ & 2 & $\% 33,3$ \\
\hline & İklim & - & - & - & - \\
\hline & Ormanlar & 3 & $\% 1$ & 3 & $\% 50$ \\
\hline & Bitki Örtüsü & - & - & - & - \\
\hline & Tabii Güzellikler & 25 & $\% 8,1$ & 5 & $\% 83,3$ \\
\hline & Doğal Kaynaklar & 10 & $\% 3,3$ & 4 & $\% 66,7$ \\
\hline & Koylar & 4 & $\% 1,3$ & 3 & $\% 50$ \\
\hline & Manzara & 9 & $\% 2,9$ & 4 & $\% 66,7$ \\
\hline & Akarsular & 1 & $\% 0,3$ & 1 & $\% 16,7$ \\
\hline & Dağlar & 3 & $\% 1$ & 2 & $\% 33,3$ \\
\hline \multirow{8}{*}{ 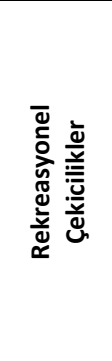 } & Su Aktiviteleri & 7 & $\% 2,3$ & 2 & $\% 33,3$ \\
\hline & Parklar ve Bahçeler & 4 & $\% 1,3$ & 3 & $\% 50$ \\
\hline & Dinlendirici Faaliyetler & 11 & $\% 3,6$ & 4 & $\% 66,7$ \\
\hline & Doğa Aktiviteleri & 4 & $\% 1,3$ & 3 & $\% 50$ \\
\hline & Spor Etkinlikleri & - & - & - & - \\
\hline & Alışveriş Olanakları & 6 & $\% 2$ & 3 & $\% 50$ \\
\hline & Eğlence Etkinlikleri & 10 & $\% 3,3$ & 3 & $\% 50$ \\
\hline & Fuarlar & 1 & $\% 0,3$ & 1 & $\% 16,7$ \\
\hline \multirow{6}{*}{ 美竞 } & Konaklama İşletmeleri & 17 & $\% 5,5$ & 5 & $\% 83,3$ \\
\hline & Yiyecek İçecek işletmeleri & 6 & $\% 2$ & 2 & $\% 33,3$ \\
\hline & Seyahat İşletmeleri & - & - & - & - \\
\hline & Limanlar-Marina & 7 & $\% 2,3$ & 2 & $\% 33,3$ \\
\hline & Ulaşım Olanakları & - & - & - & - \\
\hline & Turist Danışma Ofisleri & - & - & - & - \\
\hline
\end{tabular}


Grafik 1: Kültürel ve Tarihi Çekicilik Unsurlarının Destinasyonlara Göre Dağılımı

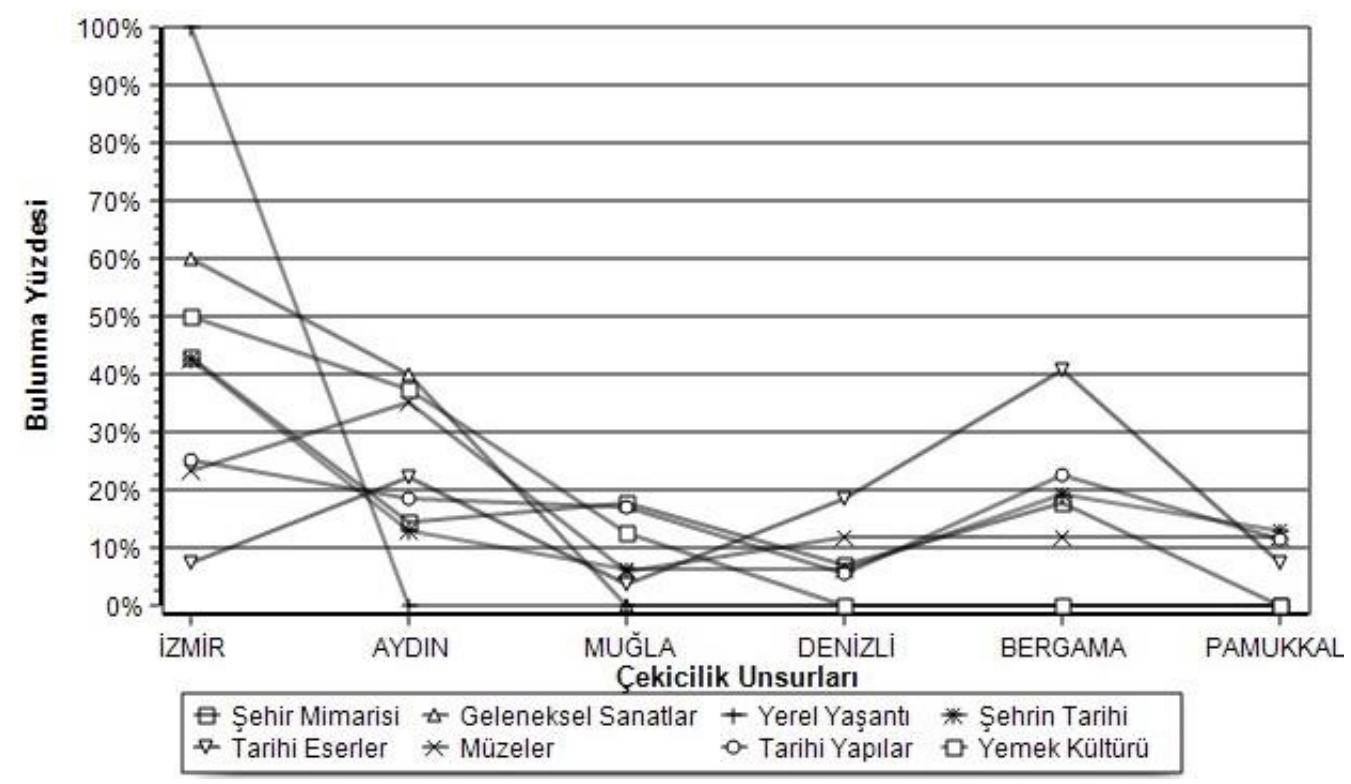

Grafik 1, kültürel ve tarihi çekicilik unsurlarının destinasyonlara göre dağıım oranlarını göstermektedir. Grafik incelendiğinde, yerel yaşantı çekicilik unsurlarının tamamının (\%100) ve yemek kültürü çekicilik unsurlarının yarısının (\%50) İzmir destinasyonu ile ilgili tanıtım bilgilerinde yer aldığı görülmektedir. Bununla birlikte, şehir mimarisi $(\% 42,9)$ ve şehrin tarihi $(\% 42,6)$ çekicilik unsurlarına İzmir destinasyonuyla ilgili bilgilerde daha fazla yer verildiği, geleneksel sanatlarla ilgili çekicilik unsurlarının tamamının birbirine yakın oranlarda İzmir (\%60) ve Aydın (\%40) destinasyonlarında yer aldıkları, müzeler çekicilik unsuru ile ilgili bilgilerin ise en fazla Aydın destinasyonunda $(\% 35,3)$ yer aldığı dikkat çekmektedir. Tarihi yapılarla ilgili çekicilik unsurlarının ise en fazla İzmir $(\% 25,0)$ ve Bergama $(\% 22,6)$ destinasyonlarında yer aldığı analizler sonucu grafikten elde edilen diğer bulgular arasındadır.

Ege bölgesindeki altı destinasyonun doğal çekicilik unsurlarına ilişkin kodların dağlımı Grafik 2'de gösterilmektedir. Grafik incelendiğinde, deniz ve sahiller $(\% 57,7)$, koylar $(\% 55,6)$, manzara $(\% 46,2)$ çekicilik unsurlarının en fazla yer aldığı destinasyonun Muğla olduğu görülmektedir. Göller çekicilik unsuru Aydın (\%50) ve Muğla (\%50), akarsular çekicilik unsuru ise Muğla (\%50) ve Denizli (\%50) destinasyonlarında eşit oranda yer almaktadırlar. Benzer şekilde, ormanlar çekicilik unsuru Denizli (\%40) ve Bergama (\%40) destinasyonlarında, tabii güzellikler çekicilik unsuru ise Muğla $(\% 29,7)$ ve Denizli $(\% 29,7)$ destinasyonlarında eşit oranda yer almaktadır. Doğal kaynaklar $(\% 38,9)$ ve dağlar $(\% 42,9)$ çekicilik unsurlarının en fazla Denizli destinasyonuna ilişkin tanıtım bilgilerinde yer aldığı grafikten anlaşılmaktadır. 
Grafik 2: Doğal Çekicilik Unsurlarının Destinasyonlara Göre Dağılımı

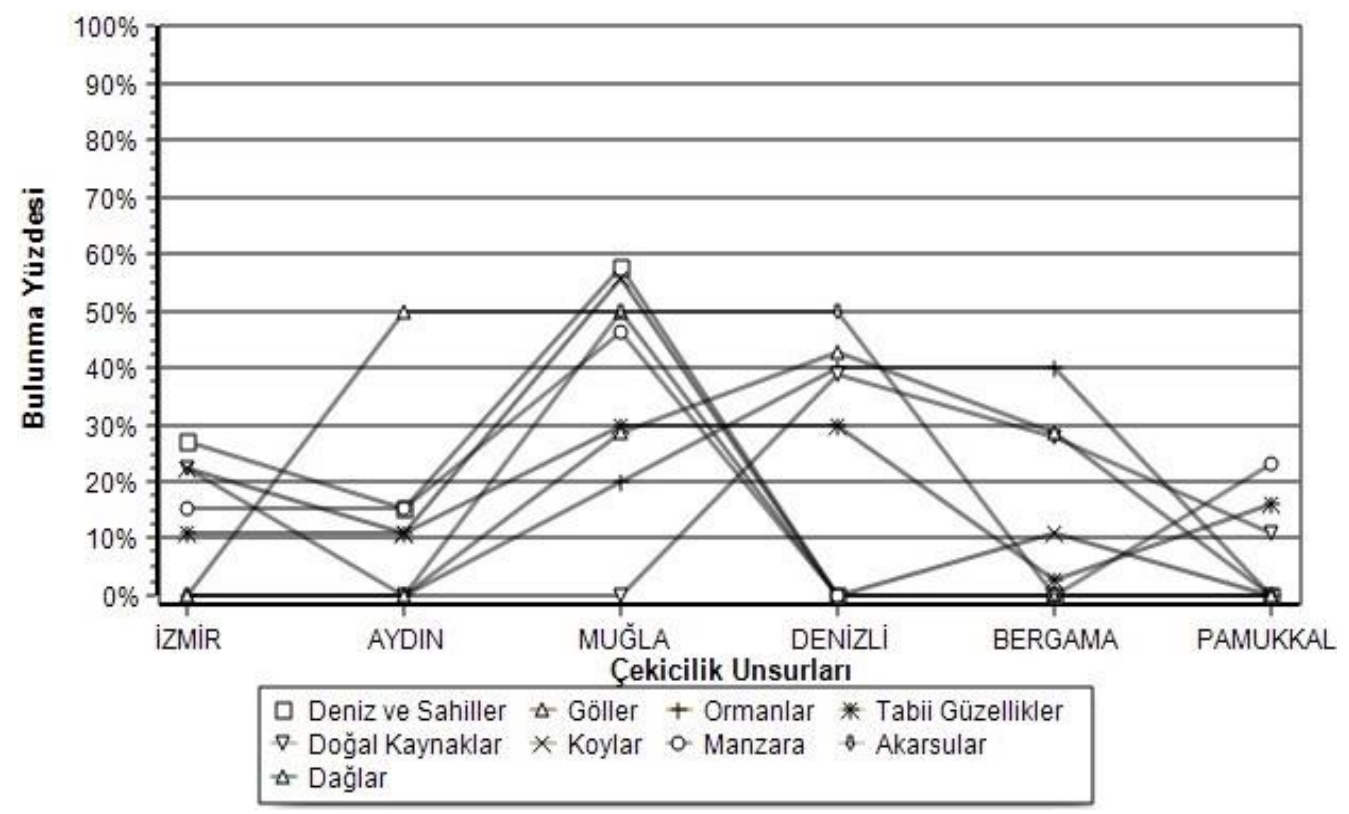

Grafik 3: Rekreasyonel Çekicilik Unsurlarının Destinasyonlara Göre Dağılımı

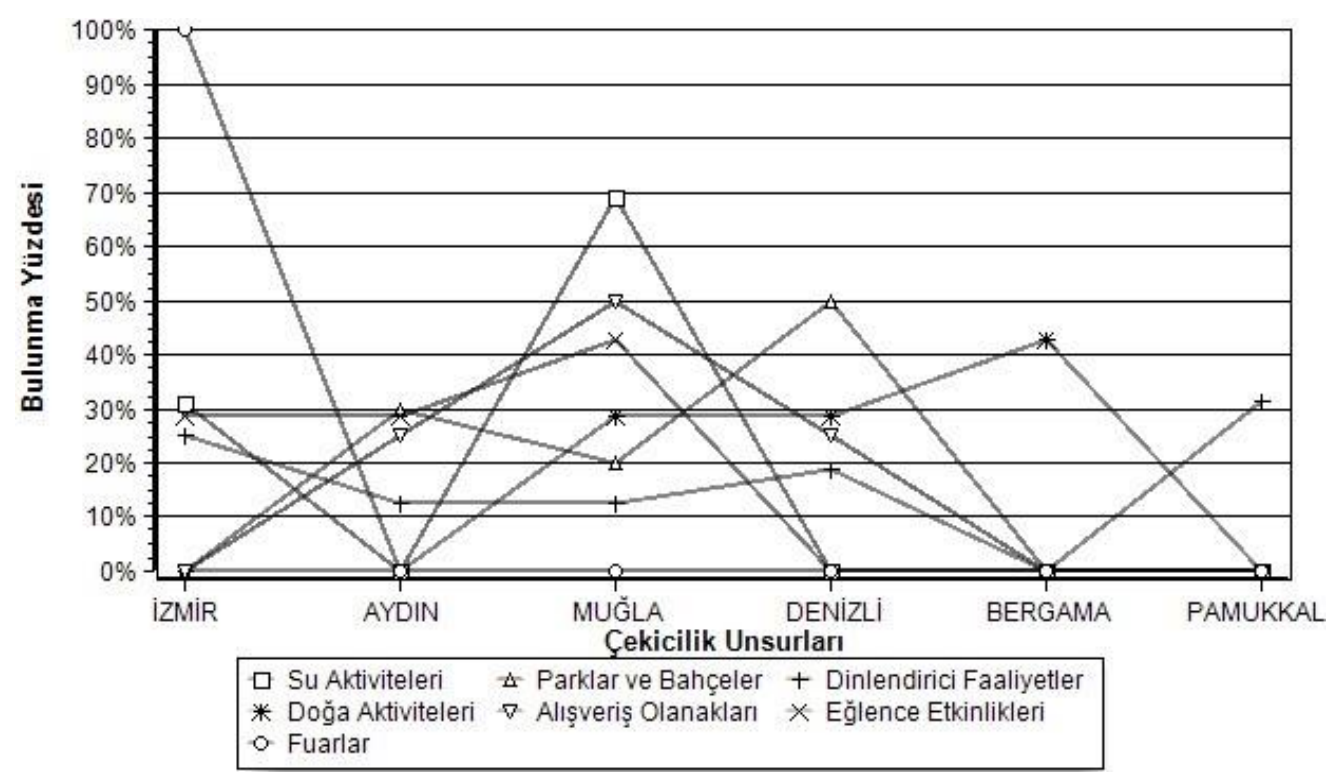

Rekreasyonel çekicilik unsurlarının destinasyonlara göre dağılımı Grafik 3'te görülmektedir. Grafik incelendiğinde, su aktiviteleri $(\% 69,2)$, alışveriş olanakları $(\% 50,0)$ ve eğlence etkinlikleri $(\% 42,9)$ çekicilik unsurlarıyla ilgili bilgilerin en faza yer aldığı destinasyonun Muğla olduğu dikkat çekmektedir. Bununla birlikte, parklar ve bahçeler çekicilik unsurlarının en fazla (\%50) 
yer aldığı destinasyonun Denizli olduğu, dinlendirici faaliyetlerle ilgili çekiciliklerin ise en fazla $(\% 31,3)$ Pamukkale destinasyonuyla ilgili bilgilerde yer aldığı grafikte görülebilmektedir. Doğa aktiviteleri çekicilik unsurları en fazla $(\% 42,9)$ Bergama destinasyon bilgilerinde görülmekteyken, Muğla $(\% 28,6)$ ve Denizli $(\% 28,6)$ destinasyonlarına ilişkin bilgilerde eşit oranda yer almaktadır. Rekreasyonel çekicilikler teması altında bulunan fuarlar çekicilik unsurunun ise sadece İzmir (\%100) destinasyonuna ilişkin bilgilerde yer almakta olduğu dikkat çekici diğer bir bulgudur.

Grafik 4: Turistik Çekicilik Unsurlarının Destinasyonlara Göre Dağııımı

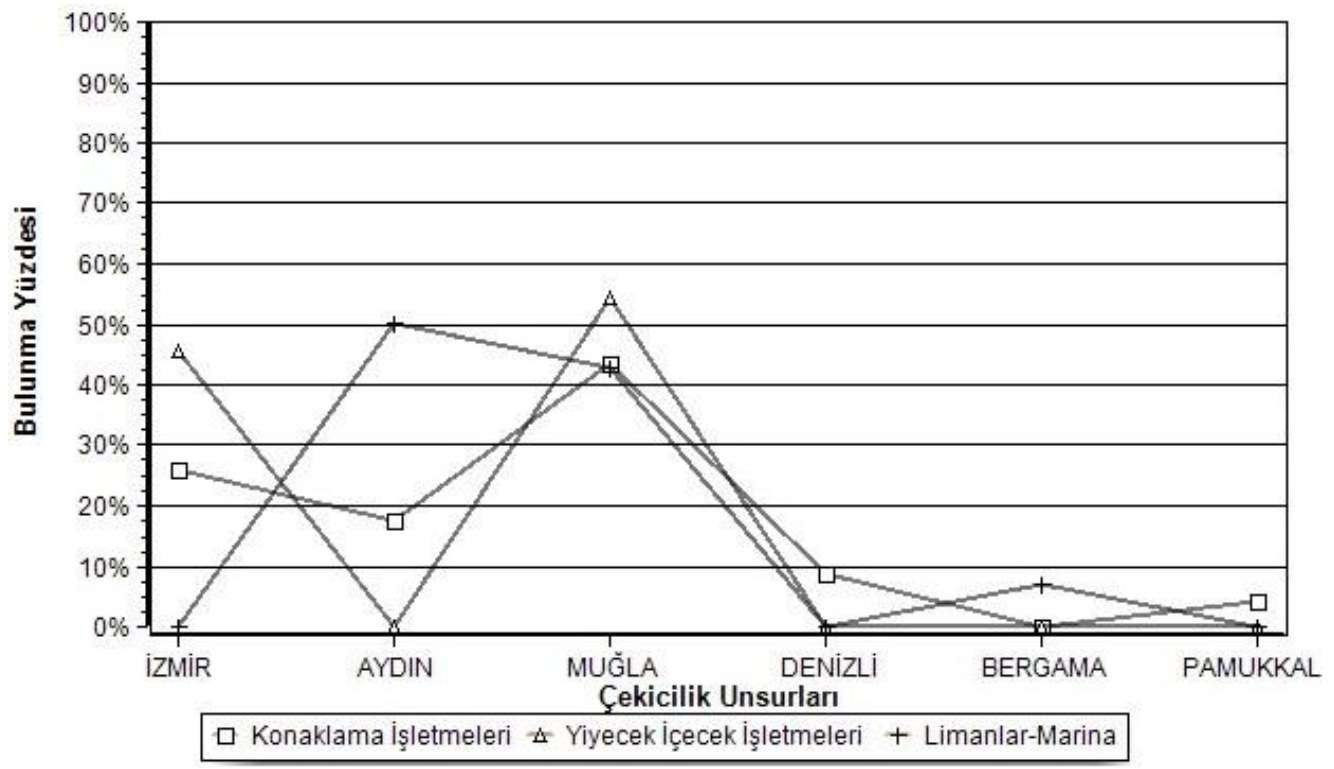

Grafik 4, turistik çekicilik unsurlarının destinasyonlara göre dağılım oranlarını göstermektedir. Konaklama işletmeleri $(\% 43,5)$ ve yiyecek içecek işletmeleri $(\% 54,5)$ unsurları hakkında en fazla bilginin yer aldığı destinasyon Muğla olarak dikkat çekmekteyken, bu destinasyonu konaklama işletmeleri $(\% 26,1)$ ve yiyecek içecek işletmeleri $(\% 45,5)$ çekicilik unsurlarında İzmir destinasyonu takip etmektedir. Limanlar-marina (\%50) çekicilik unsurlarına ilişkin en fazla bilginin yer aldığı destinasyon ise Aydın'dır. Turistik çekicilik unsurları grafiğinde, Denizli destinasyonuna ilişkin bilgilerde sadece konaklama işletmelerine $(\% 8,7)$, Bergama destinasyonunda sadece limanlar-marina $(\% 7,1)$ ve Pamukkale destinasyonuna ilişkin bilgilerde ise sadece konaklama işletmelerine $(\% 4,3)$ yer verildiği görülmektedir. 
Grafik 5: Destinasyon Çekicilik Unsurlarının Kodlanma Sıklıklarına Iliş̧kin Baloncuk Grafiği

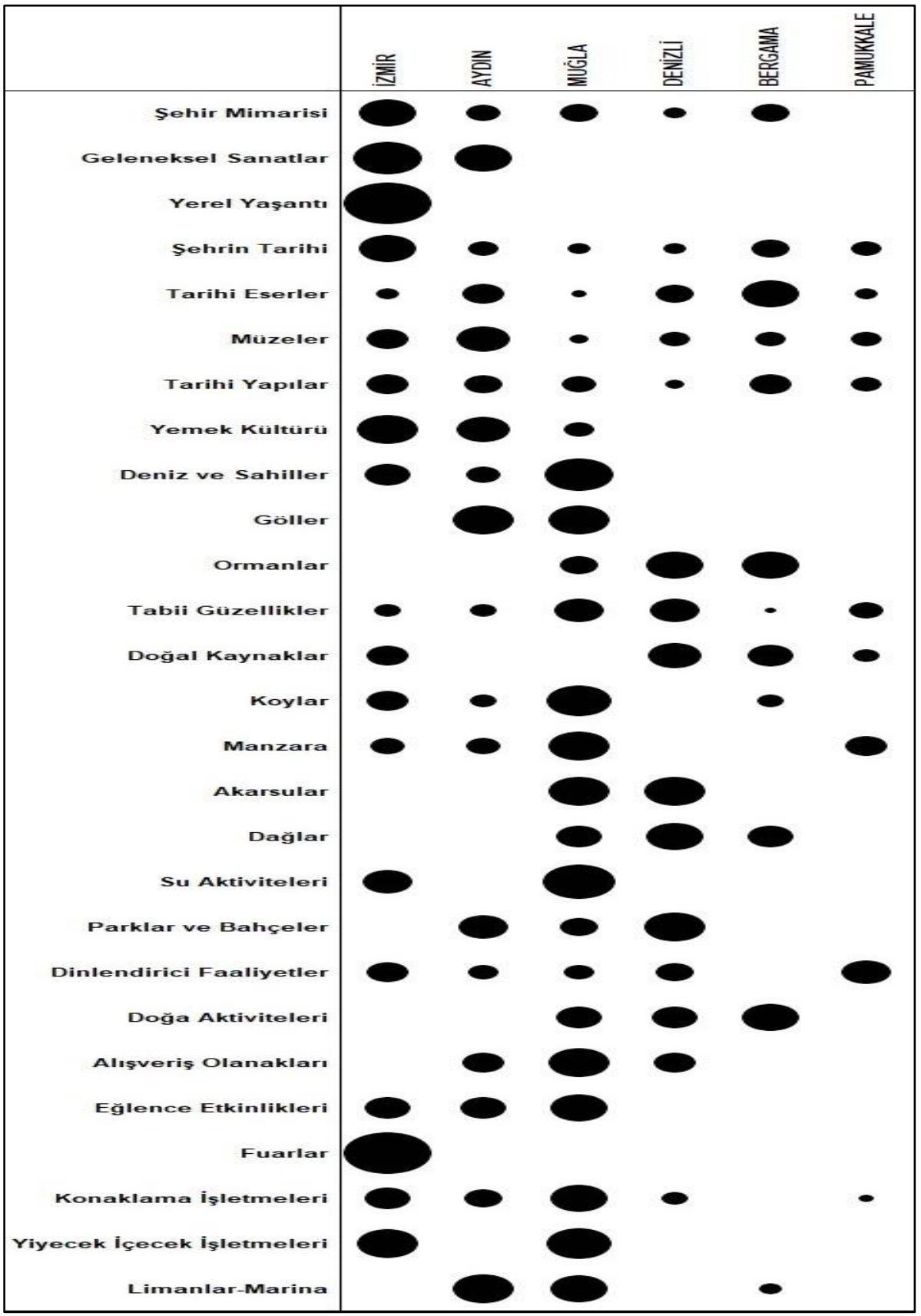


Eskişehir Osmangazi Üniversitesi iißBF Dergisi

Tablo 4: Destinasyon Çekicilik Unsurları Benzerlik Matrisi

\begin{tabular}{|c|c|c|c|c|c|c|}
\hline & İzmir & Aydın & Muğla & Denizli & Bergama & Pamukkale \\
\hline İzmir & 1,000 & & & & & \\
\hline Aydın & 0,743 & 1,000 & & & & \\
\hline Muğla & 0,652 & 0,811 & 1,000 & & & \\
\hline Denizli & 0,550 & 0,632 & 0,752 & 1,000 & & \\
\hline Bergama & 0,590 & 0,610 & 0,697 & 0,795 & 1,000 & \\
\hline Pamukkale & 0,770 & 0,720 & 0,644 & 0,774 & 0,701 & 1,000 \\
\hline
\end{tabular}

Tablo 4'te, destinasyon çekicilik unsurlarına ilişkin benzerlik oranları gösterilmektedir. Veriler incelendiğinde Aydın ve Muğla destinasyonlarına ilişkin çekicilik unsurlarının en yüksek benzerlik oranına $(\% 81,1)$ sahip olduğu görülmektedir. Bununla birlikte, Denizli ve Bergama destinasyon çekicilik unsurları arasındaki benzerlik oranı \%79,5 iken, Denizli ve Pamukkale destinasyon çekicilik unsurları arasındaki \%77,4 benzerlik oranı dikkat çekmektedir. Çekicilik unsurları açısından destinasyon benzerlikleri hiyerarşik kümeleme yöntemi ile oluşturulan ağaç grafiğinde (dendrogram) gösterilmektedir (Grafik 6).

Grafik 6: Destinasyon Çekicilik Unsurlarına Iliş̧kin Kümeleme Ağaç Grafiği

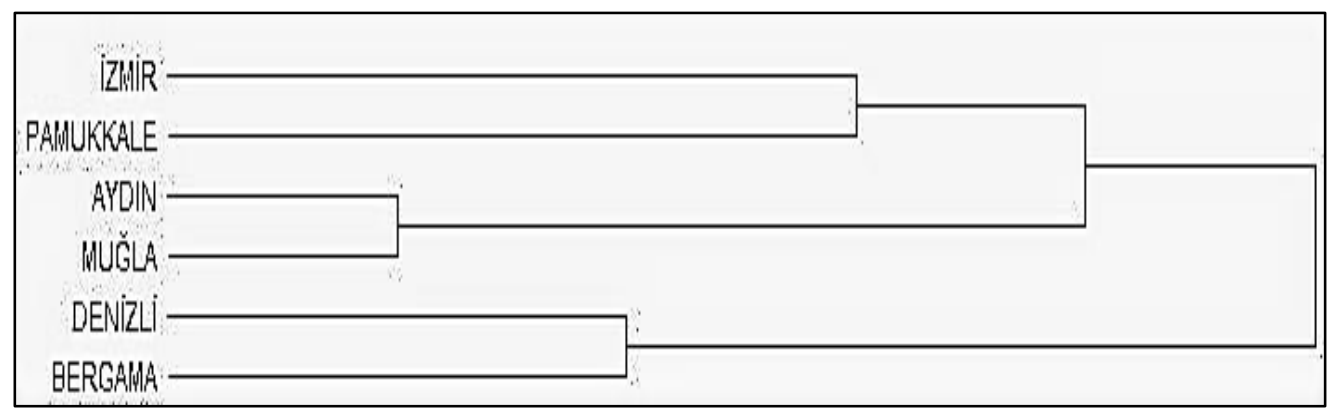

Grafik $6^{\prime}$ da, destinasyon çekicilik unsurları benzerlik oranlarına göre kümeleme analizi ile incelenmektedir. Kümeleme analizi, veritabanlarındaki verilerin gruplar veya kümeler altında toplanarak, benzer özelliklere sahip nesnelerin bir araya gelmesini sağlayan bir veri madenciliği tekniğidir. Dendrogramlar hiyerarşik kümeleme sonuçlarını göstermekte kullanılmakta, incelenen olgular birbirine benzerlik derecelerine göre belirli mesafelerde gruplar oluşturmaktadırlar. Incelenen olgular, birbirine çok benzer olduklarında birbirine en yakın mesafede gruplar oluştururken, bazı olgular ise kendine has özelliklerinden dolayı ya da diğer olgulara benzerlikleri az olduğundan tek başlarına bir grup gibi görünmektedirler (Koltan Yılmaz ve Patır, 2011: 91-108). Grafik 6'daki ağaç grafiği incelendiğinde, çekicilik unsurları açısından benzerliğin en kuvvetli olduğu destinasyon ikilisinin Aydın ve Muğla olduğu görülmektedir. Bununla birlikte, Denizli ve Bergama destinasyonlarının ikinci en kuvvetli benzerlik oranına $(\% 79,5)$ sahip olduğu, üçüncü olarak ise Pamukkale destinasyonunun Denizli'den sonra İzmir destinasyonu ile en kuvvetli üçüncü benzerlik oranına (\%77) sahip olduğu ve aralarında bir küme oluşturdukları ağaç grafiğinden elde edilen bulgulardandır. 


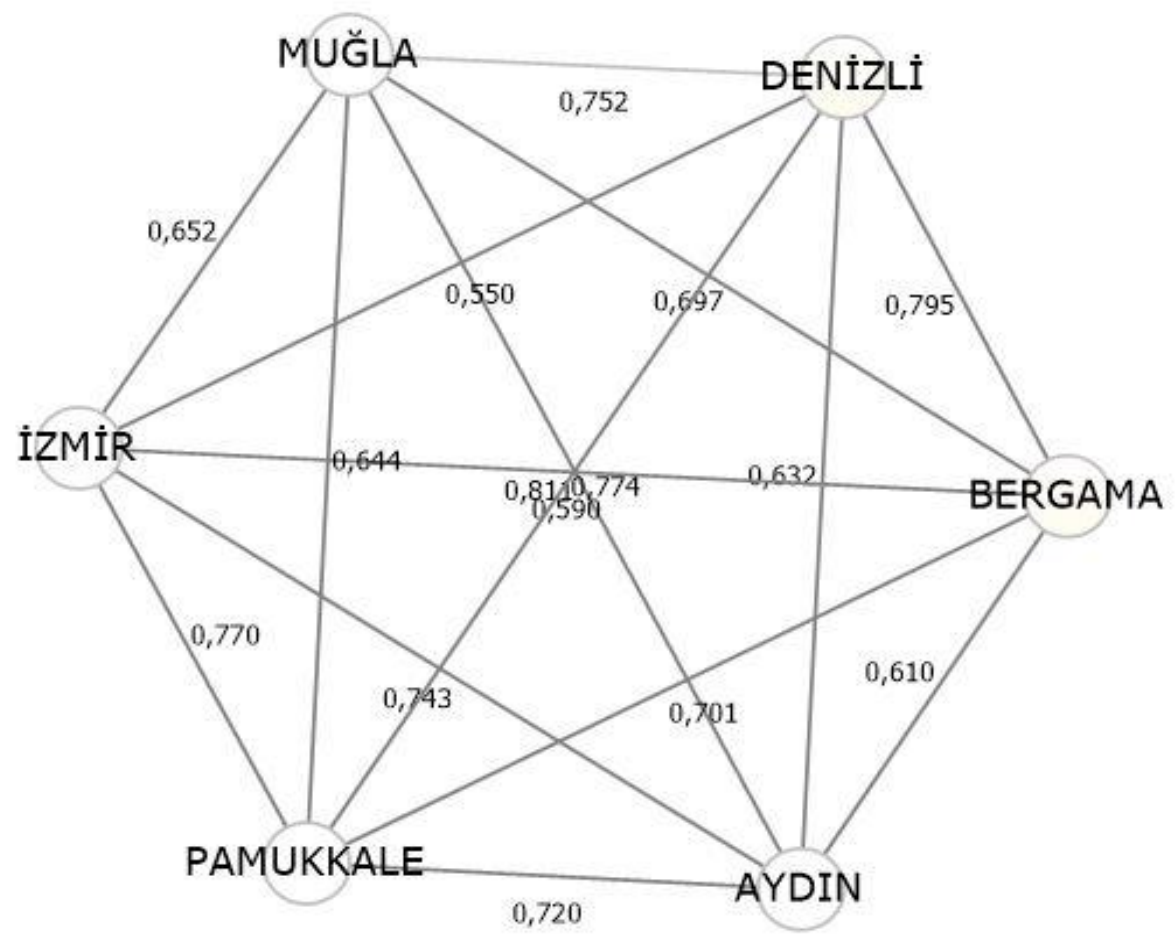

\section{Sonuç}

Turizm endüstrisinde dünya genelinde giderek artan rekabet ortamında ülkelerin destinasyon bazında çekiciliklerini ve turist sayısını artırma çabasında oldukları görülmektedir. Destinasyonların sahip olduğu çekicilik unsurları, turistlerin bir destinasyonu diğerine tercih etme sebebi olmakta ve seyahat kararlarında destinasyon çekicilik unsurlarının etkisinden söz edilebilmektedir. Bir destinasyona özgü kültürel, doğal, tarihi, rekreasyonel, turistik çekicilikler destinasyonları birbirinden farklılaştırmakta, turizm potansiyelini artırabilmektedir. Bu sebeple, potansiyel turistlere en hızlı ve etkili bir biçimde ulaşacak iletişim kanalları seçilerek destinasyonların sahip olduğu çekicilik unsurları hakkında verilen bilgiler kritik bir öneme sahiptir. Turizm faaliyetlerinin yoğunlaştığı varış noktaları olarak destinasyonlar, her biri kendine özgü çekicilik unsurlarına sahip olmakla birlikte, birbirine benzer çekicilik unsurlarını da içerebilmektedirler. Bazı destinasyonlarda kültürel ve tarihi çekicilik unsurları daha fazla yer almaktayken, bazılarında ise doğal çekicilikler daha çok ön planda olabilmektedir. Farklı çekicilik unsurlarının hepsinin bir arada bulunduğu destinasyonları, dünya genelinde en çok ilgi çeken ve ziyaret edilen destinasyonlar olarak nitelendirmek mümkündür. Bu sebeple, destinasyonların sahip olduğu turistik çekiciliklerin analiz edilerek her bir destinasyona özgü çekicilik unsurlarının eksiksiz bir şekilde tanıtım bilgilerinde yer almasının önemi açıktır.

Çevrimiçi seyahat rehberlerinde yer alan bilgilerde destinasyon çekicilik unsurlarının analizinin amaçlandığı bu araştırmada, Türkiye'nin resmi seyahat rehberi "Turkey Home” internet sitesindeki Ege Bölgesi destinasyonların İngilizce tanıtım bilgilerinden yararlanılmıştır. Muğla, Denizli, İzmir, Aydın, Pamukkale ve Bergama destinasyonlarına ilişkin bilgilerde çekicilik unsur- 
ları ayrı ayrı analiz edilerek sınıflandırılmıştır. Kültürel, tarihi, doğal ve turistik çekicilikler yönünden oldukça zengin olan bu altı destinasyona ilişkin bilgilerin analizi sonucu, en çok yer alan çekicilik unsurlarını antik kentler, camiler, kiliseler, tiyatrolar gibi tarihi yapılar ve şehrin tarihi bilgilerinin oluşturduğu tespit edilmiştir. Destinasyon tanıtım bilgilerinde en çok yer alan bu çekicilik unsurları bu araştırma kapsamındaki tüm destinasyonlarda yer almaktadır. Bu iki unsuru takiben, destinasyonun doğası, sahip olduğu yeşil alanlar, atmosfer gibi tabii güzelliklerin tanıtım bilgilerinde en çok yer alan diğer önemli çekicilik unsurları olduğu dikkat çekmektedir. Buna karşın, kültür-sanat etkinlikleri, temiz hava, iklim, bitki örtüsü, spor etkinlikleri, seyahat işletmeleri, ulaşım olanakları, turist danışma ofisleri gibi çekicilik unsurlarının hiçbir destinasyona ait tanıtım bilgilerinde yer almadığı analizden elde edilen diğer dikkat çekici bulgulardır. Oysa, bir destinasyondaki tiyatro, opera, gösteriler, sergiler, vb. kültür sanat etkinlikleri, güreş, yamaç paraşütçülüğü, gerçekleştirilen spor müsabakaları gibi spor etkinlikleri, iklim ve bitki örtüsü, konforlu, ekonomik ve alternatifli ulaşım olanakları, seyahat işletmeleri, turist bilgilendirme hizmeti sunan turist danışma ofisleri destinasyon çekiciliğini oluşturan önemli unsurlar olarak değerlendirilmektedir (Kızılırmak, 2006; Kılıç vd., 2011; Kutvan ve Kutvan, 2013; Tatar vd., 2017). Bu sebeple, araştırma kapsamındaki destinasyon bilgilerinde söz konusu çekicilik unsurlarının yer almaması, destinasyonların potansiyelleri dikkate alındığında önemli bir eksiklik olarak değerlendirilebilir. Bir destinasyonun diğerine tercih edilmesini sağlayacak bu çekicilik unsurlarının tanıtım bilgilerinde yer alması, destinasyonlara yönelik ziyaretleri artırabilecek ve rekabet avantajı sağlayabilecektir.

Araştırma bulguları destinasyon bazında incelendiğinde, destinasyon çekicilik unsurlarının farklılaştığı, bazı unsurların sadece tek bir destinasyonda yer aldığı, bazı destinasyonlarda ise birtakım çekicilik unsurlarının hiç yer almadığı görülmektedir. Fuarlar ve modern, geleneksel yaşam tarzını yansıtan yerel yaşantı çekicilik unsurları, sadece İzmir destinasyonuyla ilgili bilgilerde yer almaktayken, destinasyon çekicilik unsurlarının en sık yer aldığı Muğla'da geleneksel sanatlar, yerel yaşantı, doğal kaynaklar gibi çekicilik unsurlarına tanıtım bilgilerinde hiç yer verilmemesi dikkat çekmektedir. Deniz ve sahilleri, doğası, koyları ve yelken, tekne gezileri, su sporları gibi su aktiviteleriyle ilgili çekicilikleriyle ön plana çıkan Muğla destinasyonunda, geleneksel el sanatları, şifalı sular, modern ve geleneksel yaşam tarzını içeren yerel yaşantı gibi var olan çekicilik unsurlarına da tanıtım bilgilerinde yer verilmelidir.

Turistik çekicilik unsurlarına ilişkin bilgilerin özellikle İzmir, Aydın ve Muğla destinasyonlarında yoğunlaştığı, Denizli, Bergama ve Pamukkale destinasyonlarına ilişkin tanıtım bilgilerinde bu çekicilik unsurlarına oldukça az yer verildiği ya da hiç yer verilmediği analizlerde tespit edilen diğer bir eksiklik olarak görülmektedir. Limanlar-marina çekicilik unsurları hakkında bilgilerin bulunmayışı, Pamukkale ve Denizli destinasyonlarında bu unsurların mevcut olmaması ile açıklanabilirken, konaklama ve yiyecek içecek işletmeleri çekicilik unsurlarına ilişkin bilgilerin çok düşük düzeyde bulunması dikkat çekicidir. Bir destinasyonda yer alan konaklama işletmeleri ve yiyecek içecek işletmeleri turistlerin bir destinasyonu ziyaret etmelerinde etkili çekicilik unsurları olarak yapılan araştırmalarda ortaya konmaktadır (Formica ve Uysal, 2006; Henderson, 2010). Özellikle bir destinasyonun yemek kültürünü yansıtan yiyecek içecek işletmeleri, destinasyonlar için önemli bir çekim gücü oluşturmaktadırlar (Karaçar ve Göker, 2016; Aydoğdu ve Duman, 2017). Bu bakımdan mevcut konaklama ve yiyecek içecek işletmelerine tanıtım bilgilerinde daha fazla yer verilmesi, bu destinasyonlara yönelik çekiciliği artırmada önemli unsurlar olarak değerlendirilmeli ve bu unsurlara daha çok vurgu yapılmalıdır.

Tanıtım bilgilerinde yer alan destinasyon çekicilik unsurlarının benzerlik oranlarına ilişkin veriler, en yüksek benzerliğe Aydın ve Muğla destinasyonlarının sahip olduğunu göstermekte- 
dir. Burada, kültürel ve tarihi, doğal, rekreasyonel ve turistik çekicilik unsurlarının bu iki destinasyon arasında benzer şekilde dağılım gösterdiğini, birbirine yakın destinasyon çekiciliklerine sahip olduklarını ifade etmek mümkündür. Bu iki destinasyonun birbirine diğer destinasyonlara göre daha yakın mesafede olmalarının, bu benzerlikte etkili olduğu düşünülebilir. Destinasyon çekicilik unsurlarının dağılımı bakımından Denizli ve Bergama destinasyonlarının ikinci, Denizli ve Pamukkale destinasyonlarının üçüncü sırada birbirine benzediği görülmektedir. İzmir'in ise en yüksek benzerlik oranına sahip olduğu destinasyonun Pamukkale olduğu dikkat çekmektedir. Bulundukları bölge itibari ile aynı konumda olan bu destinasyonların benzer çekicilik unsurlarına sahip olmaları ve en benzer iki destinasyonun Aydın ve Muğla olması, bu destinasyonların kendi aralarındaki rekabeti açısından da önem taşımaktadır. Bu destinasyonların rekabet avantajı elde etmelerinde sahip oldukları benzer çekicilik unsurlarının yanında turizm işletmeleri, yemek kültürü, etkinlikler, vb. çekicilik unsurlarına daha çok önem verilmesi, tanıtım bilgilerinde daha fazla yer alması gerektiği ifade edilebilir. Destinasyonların birbirinden farklılaşması açısından bu hususların belirleyici olmaları muhtemeldir.

Çevrimiçi seyahat rehberlerinde yer alan tanıtım bilgileri analiz edilerek destinasyon çekicilik unsurlarının tespit edildiği bu araştırma, "Turkey Home" internet sitesinde yer alan Ege bölgesindeki altı destinasyonun bilgileri ile sınırlıdır. Benzer yöntemlerle ileride yapılacak araştırmalarda, destinasyon tanıtımı içerikli farklı internet siteleri, sosyal medyada kullanıcılar tarafından yapılan destinasyon yorumları, tanıtım bilgisi içeren kurumsal mesajlar veya görsel, işitsel dokümanlar da analize tabi tutularak bulgular daha da geliştirilebilir. Anket veya mülakat gibi veri toplama teknikleri, destinasyon çekicilik unsurlarının ziyaretçilerin bakış açısıyla değerlendirilmesine olanak sağlayabilecek alternatif yöntemler olarak gelecek araştırmalarda kullanılabilir. Benzer araştırmalar farklı bölgelerdeki destinasyonlar için gerçekleştirilerek çekicilik unsurları kapsamlı bir şekilde ortaya konulabilir. 


\section{Eskişehir Osmangazi Üniversitesi IïB Dergisi}

\section{Kaynaklar}

Agusti, Daniel Paül (2018). “Characterizing The Location of Tourist Images in Cities. Differences in User-Generated Images (Instagram), Official Tourist Brochures and Travel Guides", Annals of Tourism Research, Vol. 73:103-115.

Alcantara-Pilar, Juan Miguel, Armenski, Tanja, Blanco-Encomienda, Francisco Javier, Barrio-Garcia, Salvador Del (2018). "Effects of Cultural Difference On Users' Online Experience With A Destination Website: A Structural Equation Modelling Approach", Journal of Destination Marketing \& Management, Vol. 8: 301-311.

Aydoğdu, Aydoğan, Duman, Senem (2017), “Destinasyon Çekicilik Unsuru Olarak Gastronomi Turizmi: Kastamonu Örneği”, Turizm ve Araştırma Dergisi, C. 6, S. 1: 4-23.

Blazeska, Daliborka, Milenkovski, Ace, Gramatnikovski, Sashko (2015), “The Quality of the Tourist Destinations A Key Factor for Increasing Their Attractiveness", UTMS Journal Of Economics, Vol. 6, No. 2: 341-353.

Formica, Sandro, Uysal, Muzaffer (2006), "Destination Attractiveness Based on Supply and Demand Evaluations: An Analytical Framework", Journal of Travel Research, Vol. 44, No. 4: 418-430.

Gu, Zhihui, Zhang, Yan, Chen, Yu, Chang, Xiaomeng (2016), “Analysis of Attraction Features of Tourism Destinations in a Mega-City Based on Check-in Data Mining - A Case Study of Shenzhen, China", International Journal of GeoInformation, Vol. 5, No. 11: 1-13.

Henderson, Joan C. (2010), "New Visitor Attractions in Singapore and Sustainable Destination Development", Worldwide Hospitality and Tourism Themes, Vol. 2, No. 3: 251-261.

https://www.visitbritain.com/gb/en, (Erişim: 22.01.2020).

Iglesiaz-Sanchez, Patricia P., Correia, Marisol B. Jambrino-Maldonado, Carmen (2019). "The Challenge of Linking Destination Online Reputation with Competitiveness", Tourism \& Management Studies, Vol: 15, No: 1: 35-43.

Jimenez-Barreto, Jano, Sthapit, Erose, Rubio, Natalia, Campo, Sara (2019). "Exploring The Dimensions of Online Destination Brand Experience: Spanish and North American Tourists' Perspectives", Tourism Management Perspectives, Vol. 31: 348-360.

Karaçar, Ercan, Göker, Gönül (2016), "Turizm Destinasyon Çekiciliği Unsuru Olarak Yiyecek İçecek Hizmetleri Üzerine Bir İnceleme, Çankırı Örneği", Journal of Recreation and Tourism Research, C. 3, S. 2: 73-76.

Kılıç, B., Akyurt Kurnaz, H. ve Sop, S. A. (2011). Çekici faktörlerin destinasyon seçimine etkisinin belirlenmesi ve hüzün turizmi ilişkisi. 12. Ulusal Turizm Kongresi, 30 Kasım-4 Aralık 2011, Akçakoca, Düzce, Bildiriler içinde (s. 362-370).

Kızılırmak, İsmail (2006), “Türkiye'de Düzenlenen Yerel Etkinliklerin Turistik Çekicilik Olarak Kullanılmasına Yönelik Bir İnceleme", Sosyal Bilimler Dergisi, S. 15: 181-196.

Koltan Yılmaz, Şebnem, Patır, Said (2011), “Kümeleme Analizi ve Pazarlamada Kullanımı”, Akademik Yaklaşımlar Dergisi, C. 2, S. 1: 91-113.

Kozak, Nazmi, Akoğlan Kozak, Meryem, Kozak, Metin (2012), Genel Turizm Ilkeler-Kavramlar, 12. Baskı, Ankara: Detay Yayıncılık.

Kresic, Damir, Prebezac, Darko (2011), "Index of Destination Attractiveness as a Tool for Destination Attractiveness Assessment", Tourism, Vol. 59, No. 4: 497-517.

Kutvan, Ali Bülent, Kutvan, S. Ayşe (2013), "Turizm Planlamasında Destinasyon Çekiciliklerinin Ölçümü: Bir Yöntem Yaklaşımı", Uluslararası Iktisadi ve Idari Incelemeler Dergisi, Y. 6, S. 11: 159-184.

Lever, Michael W., Shen, Ye ve Joppe, Marion (2019). "Reading Travel Guidebooks: Readership Typologies Using Eye-Tracking Technology", Journal of Destination Marketing \& Management, Vol. 14: 1-13.

Luigi, Dumitrescu, Iuliana, Cetina, Alma, Pentescu (2014). “Positioning Romania As A Tourism Destination Based On The Information From Online Travel Guides", Studies in Business and Economics, Vol. 9, No. 1: 59-65.

Medlik, S. (2003). Dictionary of Travel, Tourism \& Hospitality. $3^{\text {th }}$ Ed.,Great Britain: Butterworth-Heinemann Publications.

Miles, Matthew B., Huberman, A. Michael (1994), Qualitative Data Analysis, $2^{\text {nd }}$ Ed.,London: SAGE Publications.

Neto, Ambrozio Queiroz, Dimmock, Kay, Lohmann, Gui, Scott, Noel (2019). “Destination Competitiveness: How Does Travel Experience Influence Choice?”, Current Issues in Tourism, DOI: 10.1080/13683500.2019.1641070, 1-15.

Prebezac, Darko, Mikulic, Josip (2008), "Destinatıon Image and Key Drivers of Percieved Destination Attractiveness", Trzşste, Vol. 20: 163-178.

Saraniemi, Saila, Kylanen, Mika (2011), "Problematizing The Concept of Tourism Destination: An Analysis of Different Theoretical Approaches", Journal of Travel Research, Vol. 50, No. 2: 133-143. 
Sarı, Yaşar, Kozak, Metin (2005), “Turizm Pazarlamasına İnternetin Etkisi: Destinasyon Web Siteleri İçin Bir Model Önerisi", Akdeniz iiBF Dergisi, S. 9: 248-271.

Şen Demir, Şirvan (2010), "Çekici Faktörlerin Destinasyon Seçimine Etkisi: Dalyan Örneği”, Ege Akademik Bakış, C. 10, S. 3: 1041-1054.

Şimşek, Hüseyin (2009), "Eğitim Tarihi Araştırmalarında Yöntem Sorunu”, Ankara Üniversitesi eğitim Bilimleri Fakültesi Dergisi, C. 42, S. 1: 33-51.

Tatar, Selma, Atak, Onur, Tunaseli, Arda (2017), "Bir Turistik Çekicilik Örneği: Tiyatro Medresesi”, Uluslararası Sosyal Araştırmalar Dergisi, C. 10, S. 53:978-985.

Ural, Ayhan, Kılıç, İbrahim (2013), Bilimsel Araştırma Süreci ve SPSS ile Veri Analizi, 4. Baskı, Ankara: Detay Yayıncılık.

Vengesayi, Sebastian; Mavonda, Felix T., Reisinger, Yvette (2009), "Tourism Destination Attractiveness: Attractions, Facilities, and People as Predictors", Tourism Analysis, Vol: 14, No. 5: 621-636.

Vijoli, Cristina, Marinescu, Nicolae (2016). "Analyzing The Online Promotion of a Tourist Destination: The Case of Saariselkä", Bulletin of the Transilvania University of Brasov. Series V: Economic Sciences, Vol. 9(58), No. 2: 153162.

www.tdk.gov.tr, (Erişim: 25.02.2019). 


\title{
Extended Summary
}

\author{
Analysis of Destination Attractiveness Factors in Online Travel Guides: The Case of "Home Turkey"
}

In the tourism industry, where countries compete intensely with each other, tourist destinations emerge as an important determining factor in obtaining competitive advantage. Today, countries attach more importance to promotion activities in the national and international arena on the basis of destinations and use various communication channels for this purpose. The online travel guides created for promotional purposes attract attention as one of the most effective methods of reaching potential visitors. In these online resources, general information transportation, location, etc. related to destinations along with various attraction elements are included in the destination. Therefore, it is possible to qualify online travel guides as important sources of destination attractions. In this context, the purpose of this research is to analyze the destination attractions in the online travel guides and to obtain descriptive information. Destination attraction elements are categorized, which attracts more attention to destination information, distribution of attraction elements on a destination basis, and revealing missing elements, reaching potential visitors and increasing attraction to the destination. In this research, destination promotional texts on the Turkey's official online travel guide "Turkey Home" was used (https://hometurkey.com/en/). Within the scope of the research, six destinations (Izmir, Mugla, Aydın, Denizli, Pamukkale, Bergama), which are visited intensely by local and foreign tourists, and which are given information on the "Turkey Home" website in the Aegean region, were selected as sample. In the research, document analysis technique was used as a data collection tool. These data collected in accordance with the purpose of the research were analyzed using the content analysis method.

When the distribution of cultural and historical attraction elements according to destinations is examined, it is seen that all of the local life attraction elements and half of the food culture attraction elements are included in the promotional information about İzmir destination. However, it is noteworthy that the city architecture and the city's history attraction elements are given more information about the Izmir destination that all the elements of attraction about traditional arts are located in the Izmir and Aydın destinations in close ratios, and the information about the attraction element of the museums is mostly in the Aydın destination. When the findings related to natural attraction elements are analyzed, it is seen that the destination where the sea and beaches, bays and landscape attraction elements are located most is Mugla. Lakes attraction element in Mugla and Aydın and the streams attraction element in Mugla and Denizli are equally located. Similarly, forests attractiveness element in Denizli and Bergama destinations, and natural beauty attraction elements in Mugla and Denizli destinations are equally located. When the distribution of recreational attraction elements by destination is examined, it is remarkable that the destination with the most information about water activities, shopping opportunities and entertainment activities is Mugla. However, it can be seen that the destination with the most attractive elements parks and gardens is Denizli, and the attractions about the relaxing activities are the most in the information about the Pamukkale destination. When the distribution of tourist attraction elements according to destinations is examined, the destination that has the most information about accommodation and food and beverage business elements attracts attention as Mugla. The most information about these attraction elements is located in the Izmir destination after the Mugla destination. The destination with the most information regarding ports-marina attraction elements is Aydın. It is seen that in touristic attraction elements, the information about Denizli destination includes only accommodation establishments, only the ports and marina in the information about Bergama destination and only accommodation establishments regarding Pamukkale destination information.

When the similarity ratios of destination attraction elements are analyzed, it is seen that the attraction elements of Aydın and Mugla destinations have the highest similarity rate. However, the similarity ratio between the destination attraction elements of Denizli and Bergama destinations is second, and the similarity between the destination attraction elements of Denizli and Pamukkale destinations is in the third place. As a result of the analysis of the information related to these six destinations, it was determined that the most important attractions are the historical structures such as ancient cities, mosques, churches, theaters and the city's history. These attraction elements, which are included in the destination promotional information are found in all destinations within the scope of this research. On the other hand, other remarkable findings obtained from the analysis that attraction elements such as cultural and artistic activities, fresh air, climate, vegetation, sports events, travel businesses, transportation facilities, tourist information offices are not included in the promotion information of any destination. The absence of such attraction elements in the destination information within the scope of the research can be considered as an important deficiency considering the potentials of the destinations. It is seen that the information about the tourist attraction elements is more in the Izmir, Aydın and Mugla destinations. It is seen as another deficiency found in the analysis that the touristic attraction elements are given little or no place in the promotional information about Deni- 
zli, Bergama and Pamukkale destinations. Giving more information to the existing accommodation and catering businesses in promotional information should be considered as important factors in increasing the attractiveness of these destinations and more emphasis should be placed on these elements.

The data on the similarity ratios of the destination attraction elements in the promotional information show that the Aydın and Mugla destinations have the highest similarity. From this point of view, it is possible to state that cultural and historical, natural, recreational and touristic attractions are similarly distributed between these two destinations, and they have close proximity destination attraction elements. It may be thought that the closeness of these two destinations to each other than other destinations is effective in this similarity. In terms of the similarity of destination attraction elements, it is seen that Denizli and Bergama destinations are second and Denizli and Pamukkale destinations are third. In terms of destination attraction elements, Izmir and Pamukkale destinations stand out as the most similar destinations. The fact that these destinations, which are in the same geographic location as their region, have similar attraction elements is also important for the competitiveness of these destinations. In addition to the similar attraction elements that these destinations have in obtaining competitive advantage, tourism enterprises, food culture, activities, etc. It can be stated that more attention should be paid to the elements of attraction and more information should be included in the promotional information. These are likely to be decisive in terms of differentiating destinations. 
Eskişehir Osmangazi Üniversitesi IißBF Dergisi 